\title{
DEMOCRATISATION OF GREEK SOCIETY DURING THE ARCHAIC ERA?
}

\author{
Mait Kõiv
}

In the modern scholarship of the Ancient Greek history there is a well known and well established conception of an universal democratisation of Greek society during the Archaic and Early Classical periods. It could be summarised roughly as follows: ${ }^{1}$ After the fall of the Bronze Age Mycenaean civilisation, in the so-called Dark Ages (11th to 8th centuries B.C.), the Greek communities were governed by the kings (basilees). Since their power was limited by the nobility, one could speak about aristocratic monarchy: the king (essentially the first among equals) and the nobles ruled, while the common people had factually no share in the government - they were present in the assembly but only for listening and obeying to what the best (the king and the nobles) said and decided. ${ }^{2}$ At the beginning of the Archaic era, roughly in the 8th century, the kingship was gradually abolished and replaced by a collegial rule of the nobility - an aristocratic republic. This development has sometimes been considered to be the true beginning of Greek city state. ${ }^{3}$ However, the common people were still left without any considerable political power. ${ }^{4}$ But thereafter, during the following Archaic period (7th-6th centuries), the social and political consciousness and importance of the commoners began to rise. ${ }^{5}$ This was caused, in a great extent, by the development of military tactics. Until the beginning of the 7th century the battlefields were supposedly dominated by the aristocratic solo-fighters, whose combats, as a rule, decided the fate of a battle, and according to this conception, the pre-eminence in war was a main reason of the dominance of the nobles in the politics. But in the 7th century the so-called hoplite revolution took place. The battles were now fought by the array — the phalanx — of heavily equipped infantrymen - hoplites — mostly recruited from the middle class farmers outside the ruling aristocracy. Since a citizen in a Greek city state was also a soldier and vice versa, the rise of the military significance of at least a part of common people brought about the rise of their social and

\footnotetext{
${ }^{1}$ The conception can be seen, with certain modifications, from the early times of the modern historiography of antiquity up to the present: Grote 1869; Meyer 1893; Busolt 1920, 303-440; Forrest 1966; Spahn 1977; Murray 1980; Gschnitzer 1981, 27-103; Welwei 1983, 36-94; Stein-Hölkeskamp 1989; Osborne 1996; Morris 1987, 171-210; 1998.

2 On the Dark Age and the 8th century 'Homeric society' in general see Finley 1956; Qviller 1981; Donlan 1989; Ulf 1990; Van Wees 1992; a more archaeologically based account can be found in Thomas, Conant 1999. On the 'Homeric kingship' in particular, see Carlier 1984, 136-290, and an archaeologically oriented study by Mazarakis Ainian 1997. In the last decades the Homeric kings are often considered as 'chiefs' according to the anthropological terminology (Qviller 1981; Donlan 1989; 1997; Ulf 1990), but this has not basically altered the picture of the rule by a single man. A different point of view is presented by Drews 1983, who denies the reality of the 'Homeric kingship' (the opinion of Andreev 1979 also seems to be relatively close to that of Drews).

${ }^{3}$ Ehrenberg 1937; Snodgrass 1980, 15-84; Polignac 1984; Starr 1986, 23-33, 35-42; Morris 1987 , especially 183-196; 1998, 71-73.

${ }^{4}$ Morris' view $(1986 ; 1987,171-210 ; 1998)$ is exceptional in this respect. He dates the rise of the common people already to the 8 th century.

${ }^{5}$ Here Starr 1986 differs from the others, he suggests that before the 7th century the aristocrats were only establishing their power, that the 7 th century was the peak of the aristocratic dominance, and that their gradual retreat began mostly only in the 6th century.
} 
political importance as well. The result was that the previously rather inert commoners gradually began to demand and obtain more share in the government, so that at least in the 6th century some city states became more democratic. ${ }^{6}$ In many cases the fall of aristocratic rule was induced by the tyrants - the noble leaders usurped the power in the state as the champions of the discontent commoners. ${ }^{7}$ As a result of this development, the classical Greek democracies emerged in the 5th century, in which all the citizens, including the common people, had equal political rights. The best example of this is certainly the democratic Athens.

Such conception of democratisation of Greek communities is often taken not only as a general tendency but almost as the universal rule of the development of Greek society, which even allows us to fill the gaps in our knowledge of the history of particular city states. So, when speaking about the Dark Age, one feels justified to admit without further discussion that any community was led by a king, and in the case of the early Archaic age, that it was governed by aristocrats. And when we have some evidence which cannot be securely dated, one usually arranges it according to this conception - all evidence suggesting kingship (that is, if the monarch is called in the sources a king and not a tyrant) is considered the earliest, the evidence concerning aristocracy the next, and all that is pointing to the common people participating in political power, the latest.

This conception, in certain extent, is based on the point of view of Aristotle. Indeed, in his 'Politics' Aristotle stated that in the old heroic times the communities were ruled by hereditary kings with established rights, and later their rule was replaced by aristocracies and oligarchies which were in turn overthrown by the tyrannies and thereafter replaced by the democratic governments. Aristotle pointed also to the connection of the warfare and government: as long as the main force in the battlefield was cavalry, the full citizenship was limited to the few rich (that was the time of the kings and early aristocracies); but when the cities grew and the hoplites became stronger, more people were admitted to the politeia and the states developed in the direction of democracy; and last, in some states as in Athens, whose military might was based on the navy in which the poor served, the radical form of democracy ochlokratia (the power of the mob) as Aristotle called it - often emerged. ${ }^{8}$ Although this Aristotelian opinion certainly has shaped, in a way, the modern conception, the moderns rely even more on the evidence from the Homeric epics, and on the comparison of its data to that of the supposedly later sources. It is generally admitted that 'Iliad' and 'Odyssey' derive from the 8th century ${ }^{9}$ and that they reflect quite faithfully the social conditions either of their own time ${ }^{10}$ or of slightly earlier period — the Dark

\footnotetext{
${ }^{6}$ Meyer 1893, 512-517; Nilsson 1929; Andrewes 1956; Forrest 1966, 95; Cartledge 1977; Murray 1980, 120-139, 159; Snodgrass 1980. See also Snodgrass 1965.

${ }^{7}$ On the tyrants as anti-aristocratic leaders see Meyer 1893; Oliva 1960; Forrest 1966, 104-105; Mosse 1969; Murray 1980, 132-152. The connection between the hoplites and tyranny has been pointed out especially by Andrewes 1956; Forrest 1966, 105, 112-114; Salmon 1977; Murray 1980, 132-139. In the recent years some authors have been, admittedly, more critical about the anti-aristocratism of the tyrants: Stahl 1987; Cawkwell 1996; Libero 1996.

${ }^{8}$ The crucial passages are Pol. 1285b, $1286 \mathrm{~b}$ and $1297 \mathrm{~b}$. But see also $1289 \mathrm{~b}$ (the connection of aristocracy and cavalry) and $1310 \mathrm{~b}$ (the democratic character of the early tyranny). This conception was followed quite consistently in the Athenaion Politeia.

${ }^{9}$ This date has been recently pointed out most vigorously by Janko 1982, 228-231 (linguistic arguments) and Morris 1986, 91-94 (historical arguments).

${ }^{10}$ Gschnitzer 1981, 28; Morris 1986; with some reservations also Van Wees 1992.
} 
Age. ${ }^{11}$ Therefore, almost everything we find in the poems, except some obvious anachronisms (such as the use of the bronze weapons, the geography of the Mycenaean age and some recognisable Mycenaean objects) have been assigned either to the Dark Age or to the 8th century. These centuries have becomethe 'Homeric Age', for which, by the very virtue of the definition, the epics give good and almost contemporary evidence. ${ }^{12}$ On the other hand, all the phenomena that are not directly reflected in the poems have been considered as the result of a later, 'post-Homeric' development. Thus, since in the epics every community was ruled by a king (basileus) while from the Archaic lyric poetry we do not hear anything about the contemporary kings but only about the tyrants, it is admitted that the kingship in a truly 'Homeric' fashion was as a normal thing until the 8th century after which it was abolished, and the tyranny rose only in the 7th century. Since in the epic assemblies the noble heroes speak and make decisions, and the commoners are usually silent, while from the lyrical poetry and the later traditions we know about the commoners' social and political pretensions, the rise of the political consciousness of the common people must belong to the post-Homeric world. And since in the epics we find the heroes fighting duels, while from the 7th century art and poetry we have incontestable evidence of the hoplite phalanx, the latter must have been developing only from the 7th century onwards.

Such conception is certainly a convenient one. We have no literary sources about the time before Hesiodos (c. 700), other than, possibly, the Homeric epics, and we possess only relatively meagre archaeological data. Therefore, it is temptingto fill up the gap in our knowledge with the admittedly rich Homeric data, and, on the other side, it is virtually impossible to check the correctness of such assumption - there is simply not enough contemporary data that the Homeric evidence could be compared to. No surprise, then, that this conception is so readily accepted.

But at the same time all the basic assumptions of this conception could be and have been questioned.

1) As it has been said, the point of view under consideration suggests that the epics give a historically credible picture of the recent past or of the contemporary time of the poet. But we cannot be certain in it. Indeed, the oral epic tradition has very ancient roots, it almost certainly flourised in the Mycenaean Bronze Age, and has been transmitted through several epochs. ${ }^{13}$ Homeric poems certainly have preserved some features that can be proved to derive from the Bronze Age, already noted above. ${ }^{14}$ In most cases, unfortunately, any proof is impossible. However, our disability to give positive proofs on the contrary does allow assigning all other epic institutions and practices to the poet's recent times. The poet and the audience were certainly well aware that the epics were depicting a distant past different of their own time, and as the obvious anachronisms in the poems show, they were at least in some extent able to imagine it. In addition, one must always take in count the possibility of the poetic exaggeration - a deliberate attempt to make the epic world more wonderful, heroic etc. Therefore, there are good grounds for considering the epic world to be a poetically

\footnotetext{
${ }^{11}$ Finley 1956; Dickinson 1986; Raaflaub 1998.

12 That the 'Homeric world' is a reliable depiction of the 'pre-state community' in Greece is, of course, an almost universally accepted assumption: Spahn 1977, 29-58; Murray 1980, 38-68; Quiller 1981; Runciman 1982; Stein-Hölkeskamp 1989; Donlan 1989; Ulf 1990; Walter 1993, 29-44.

${ }^{13}$ See especially West 1973; 1988.

${ }^{14}$ Perhaps still the best treatment of the problem is Lorimer 1950.
} 
arranged mixture of the traits of different ages, and there is little warrant taking it for a faithful representation of any historical period. ${ }^{15}$

2) We do not know in fact when and how the epics were composed, or in other words, which were these recent and/or contemporary times of the poet that he may have depicted. The usual assumption that the poems date from the 8th century is, in fact, only a hypothesis, accepted widely but not universally. In recent years some prominent scholars (W. Burkert, M. West, H. v. Wees) have strongly suggested a 7th century date for the poems. ${ }^{16}$ In addition, there is also the point of view of G. Nagy, who takes the formation of the epics as a gradual process of oral composition and recomposition, which continued during almost the whole Archaic period. The 8th century was, according to his view, a formative period in this process, while the oral transmission and therefore a perpetual re-composition did not end until the writing down of the epics in the second half of the 6th century. ${ }^{17}$ If we accept this conception of the gradual formation and late literary fixation of the epics, the Homeric world would become a picture of epic past that developed during the whole course of the Dark Age and Archaic period. In that case it would be even more difficult to single out any particular time as 'The Age of Homer', the 'Homeric world' would contain the features from very wide spectre of times from the Bronze Age to the 6th century.

In any case, there are good grounds for questioning the conception of the 'Homeric world' as a reliable reflection of the social conditions of the Dark Age and/or the 8th century. And if it must be considered, instead, as a poetically arranged mixture of different ages, it obviously cannot be used in a straightforward way for the reconstruction of any one of them. ${ }^{18}$

This mixture may well be apparent also in the Homeric description of the kingship. The poet certainly knew that in the 'heroic times' the cities were governed by the 'heroic kings'. Therefore, even if he had no examples of such kind of government from his own time, he might have done his best to create a picture of it out of different contemporary institutions. The 'Homeric monarchy' may be, in that case, a mixture of a vague epic memory about the 'heroic kings' of the distant past, and of various phenomena of the Archaic period: of the personal leadership in the pirate raids and colonisation, of the annual officials in different states, and of the power of the archaic tyrants. In that case there would be no historical 'Homeric kingship' as a traditionally established way of government in the Dark Age. ${ }^{19}$

But let us accept for a while that the epics do, as it is usually thought, depict quite faithfully the circumstances of the Dark Age and the 8th century (in other words, that the epics were the products of the 8 th or, perhaps, the early 7 th century, and that the Homeric society is mainly a reliable depiction of poet's own time or of recent past). Even in that case there would be serious problems with the conception of the entirely aristocratic Homeric world.

\footnotetext{
${ }^{15}$ For the Homeric world as a mixture or amalgam see Kirk 1962; Snodgrass 1974; Geddes 1984; Sherrat 1990; Osborne 1996, 152.

${ }^{16}$ Burkert 1979; Van Wees 1994, 138-146; West 1995; Osborne 1996, 156-160.

${ }^{17}$ Nagy 1990; 1992. The 6th century date for the composition of the epics has been even more vigorously suggested by Jensen 1980.

${ }^{18}$ Osborne 1996, 152.

${ }^{19}$ Drews 1983; Geddes 1984; Kõiv 1991. A critical approach towards the Dark Age Homeric kingship has been accepted also by Raaflaub 1993, 79.
} 
It is true that the epic battle descriptions focus on the combats of the heroes. But, as J. Latacz has demonstrated in his seminal work, the poet was, at the same time, well aware of the part the common people played in the war. Though the poet did not stress it, the array of soldiers - something very similar to the phalanx as we know it from the 7th century onwards - was certainly an essential feature of the 'Homeric warfare'. ${ }^{20}$ The concentration to the heroic combats in the epics could have well been only an epic devise to give the heroes the occasion to perform their heroic deeds on the battlefield. In that case there is no reason to suggest that in the 8th century the role of the common people in the battles was insignificant, and no particular grounds for postulating a 7th century 'hoplite revolution' which gave the impulse for the rise of the political significance of the commoners only from this time onwards. ${ }^{21}$

In a similar way, though in the Homeric assembly the heroes speak and decide while the common people listen and obey, there is clear evidence in the poems that the nobles must have reckoned with people's political will expressed in the assembly. ${ }^{22}$ The formal assembly - the agora — was a most essential focus-point of the Homeric public life, ${ }^{23}$ which could be considered strange if the agora had no other function than to be a place for the nobles to announce their decisions. There is also the well-known figure of Thersites in the II song of "Iliad'"24 — a common man taking speech against Agamemnon. The poet, of course, obviously denounced his behaviour and made him ridiculous, but the very fact that such occasion was depicted and that the poet felt it necessary to denounce it demonstrates that for him and his audience the voice of the common people on the assembly could have been, and probably was, a reality. In other words, the fact that the poet concentrated on the speech of the noble heroes in agora might well have been, on the one hand, again a heroic poetry's devise of focusing on the glory and the virtues of the heroes, and on the other, the result of the poet's obviously aristocratic prejudice. The social reality in his own time was probably somewhat different.

Thus, we may suggest that in the real 'Homeric world', if such a thing ever existed, the common people probably played an essential part in the battles and, accordingly, had the right and occasion to take part in the decision of the political issues in agora. Obviously these instances must have depended on each other, because, as usual in Greece, those who fought for a community must also have had the right to govern it.

Thus, all the principal premises of the modern conception under consideration are highly questionable. We do not know if the epics depicted a society of any single period (and there are grounds to suggest that they did not); even if they did, we do not know, which period exactly they depicted; and even if it was the 8th century, there is no reason to claim that in this time the common people did not participate in the warfare and in politics. There is therefore no compelling reason to consider the 8th century, differently from the following Archaic era, as a time of strictly aristocratic regi-

\footnotetext{
${ }^{20}$ Latacz 1977; Pritchett 1985, 7-33; Bowden 1993; Van Wees 1994; Raaflaub 1997. (Note Il. 4. 422429 ; 446-449; 8. 60-63; 12. 105; 13. 130-135; 16. 210-217.)

${ }^{21}$ Raaflaub 1997, 56.

${ }^{22}$ Od. 16. 370-82.

${ }^{23}$ The contrast to the uncivilised Cyclops who have neither agora nor themistes (Od. 9. 112) is certainly revealing. The importance of the institution of agora in the Homeric world has been pointed out repeatedly: Thomas 1966; Luce 1978; Scully 1990, 101-102; Van Wees 1992, 33-34; Raaflaub 1993, 54-55; Detienne 2000, 5.

${ }^{24}$ Il. 2. 211-277. See Donlan 1973, 150-151.
} 
ment, for postulating a fundamental hoplite reform in the 7th century and the rise of the power of the commoners only thereafter.

There remains, however, the point of view of Aristotle. There cannot be much doubt that Aristotle was inclined to make generalising and often somewhat schematic conceptions, sometimes, perhaps, even unwarranted by his evidence. ${ }^{25}$ And though this circumstance must not be overestimated, it is still clear that any of his conceptions depended on the evidence he used and therefore any judgement of his opinions will raise the question about his sources. ${ }^{26}$ This problem cannot be considered in any detail here. But at least it can be stated that when describing the heroic monarchy, he obviously relied on the Homeric epics, ${ }^{27}$ which he considered to be the earliest pieces of Greek literature ${ }^{28}$ and a trustworthy evidence of the real heroic world. Nor can there be much doubt that he compared it to what he considered the later evidence. Thus, his methods were, in this point, very similar to that of the moderns and, therefore, his results must also have been almost inevitably rather similar. ${ }^{29}$ When writing about the early aristocratic government after the abolishment of the heroic monarchy, he relied on some data suggesting him that in the early, but still after the end of the 'heroic era', there were the groups of mighty nobles in power in different states. ${ }^{30}$ This data, coming from the lyric poetry and the oral tradition, could scarcely have provided him good evidence about the particulars of the governmental practices. As far as it can be concluded from the examples he brought, the poetry gave him only vague evidence. ${ }^{31}$ The oral stories, on the other hand, usually tend to focus on the fabula, at the same time overlooking and modernising the social conditions. ${ }^{32}$ In addition, Aristotle certainly knew also the early laws, but this does not seem to have given

\footnotetext{
${ }^{25}$ On Aristotle's methods see Day, Chambers 1962, 12-24.

${ }^{26}$ Aristotle's opinion was in a way anticipated by Plato (Rep. 8. 544-569), who suggested a line of development: aristocracy - timocracy - oligarchy - democracy - tyranny. But Plato was about to give a philosophical picture of the deterioration of human character, caused by the neglect of ideal state-order, and it is most doubtful if he considered it as a true course of historical development. Thukydides (1.319), describing the development of early Greek society, says nothing about the democratisation (he mentions only the emergence of tyrannies instead of the heroic kings (Minos, Agamemnon and others) of the distant past - 1.13.1). It must also be noted that the Athenians in the 5th and 4th century were quite able to imagine a democracy already in the heroic time — in the time of Theseus — see Ruschenbusch 1958, 408-418.

${ }^{27}$ The obvious proofs are Pol. 1285a and 1287b, where passages from Iliad (2. 391f; 372) were relied on for the depiction of Agamemnon's power as an example. But see also the example of Kodros in $1310 \mathrm{~b} 37$. That this kind of argument was well admitted by the classical scholars is demonstrated also by Thukydides (1.3-13).

${ }^{28}$ Aristotle dated Homer a generation after the Ionian migration (fr. 66 R), i.e. immediately after the end of the Heroic Age.

${ }^{29}$ The main difference is that Aristotle as well as the other ancient authors (for example Thukydides 1. 3-12) considered the Homeric monarchy as a phenomenon of the Mycenaean era (that is the Bronze Age in our terms), while moderns place it in the Dark Age after the fall of the Bronze Age civilisation. Indeed, the ancients did not know anything about the Dark Age.

${ }^{30}$ Pol. 1289b; 1305b; 1311b. The same kind of information can be traced from different fragments of his lost Politeiai.

${ }^{31}$ Note his quotation of Alkaios in connection of the discussion of Pittakos' power (Pol. 1285a) or the mention of the verses of Tyrtaios as the evidence for social discontent in Sparta (Pol. 1306b). One must also note that even in the case of the poetry of Solon which provided him, as far as we know, the most detailed information about the social conditions (Ath. Pol. 5-12), his reconstruction of the pre-Solonian situation or of the particulars of the change the legislator brought about was obviously different from that of Androtion or Plutarchos, despite the circumstance that all they derived their evidence from Solon's poetry (compare Ath. pol. 2 and 6, 1 to Plut. Sol. 13 and 15 and Androtion FGrH 324 F 34).

${ }^{32}$ On the character of the oral tradition in general see Vansina 1985.
} 
him any clear examples of a strictly oligarchic government. At least he failed to quote such examples in 'Politics'.

In this a way, Aristotle's conception was probably basically the result of the combination of the data of the heroic epics and the stories about the noble leaders in the early cities, providing him the picture of heroic monarchy and early aristocracies, and of the probably more reliable information of the late Archaic and Classical eras, from which he knew that the common people both fought in the battles and took part in the government. Putting all this together he is likely to have induced the picture of the gradual democratisation of the society. The value of such synthesis as a reliable evidence for the real historical development is certainly rather questionable. ${ }^{33}$

It is obvious that in order to gain a proper idea of the development of Greek society and political constitution in the Archaic era, we should not rely on the heroic epics with their obscure historical setting, nor on the theories of ancient scholars, but on the contemporary evidence that undoubtedly reflected its own time: i.e. the archaeological data, the lyric poetry and the early legislation.

The evidence outside of the epics and Aristotle does not necessarily support the concept of a universal development from the 8th century monarchy and aristocracy towards the democratic forms of government. Archaeological data tells us that at least in one place - Megara Hyblaia in Sicily - a formal agora was established at the very foundation of the colony in the late 8th century. ${ }^{34}$ Obviously it implies the significance of the institution of assembly in this time, ${ }^{35}$ but it cannot tell us anything about its exact competence. From the early written laws we learn that the decisions in the cities were certainly made in the name of the whole community. ${ }^{36}$ We learn also about the existence of the assemblies, councils and different boards of magistrates in Greek communities, ${ }^{37}$ but almost nothing about the general balance of power. As far as I know, there are only two cases of the evidence which provide a relatively clear picture of the character of the politeia, both known from the literary tradition. These are the Solonian constitution in Athens and the so-called Rhetra of Lykourgos in Sparta. In both cases it is obvious that the people had a vote and some power of making decisions in the assembly. ${ }^{38}$ In the case of the Spartan Rhetra one must note that according to the ancient account it declared unequivocally the ultimate power of the whole people; ${ }^{39}$ the curtailment of this power by the so-called rider of the kings Polydoros and Theopompos came, according to the ancients, only somewhat later. ${ }^{40}$ This certainly does not suggest a democratisation, on the contrary, it suggests that, in the case of Sparta, the constitution became more oligarchic in the course of time. We have also some evidence that at least from the early 7 th century onwards the legislators gave laws with the intention to preserve the small landed property by restricting

\footnotetext{
${ }^{33}$ Recently Davies 1997, 26-27 has warned against taking Aristotle's conceptions about the formation of polis as a reliable testimony. However, it must be pointed out that this does not necessarily mean that we should argue against the reliability of the evidence that Aristotle used, but only against its ability to convey adequate information about the exact nature of the ancient statehood and society.

${ }^{34}$ Osborne 1996, 239-240.

${ }^{35}$ Detienne 2000, 5.

${ }^{36}$ Note especially the ad efade poli in the 7th century law of Dreros (Ehrenberg 1943) as well as other similar examples presented by Ehrenberg 1937.

${ }^{37}$ See Busolt 1920, 341-369; Gagarin 1986, 81-97; Gehrke 1993.

${ }^{38}$ Ath. Pol. 7. 3; Plut. Luk. 6.

${ }^{39}$ damo ... kratos in the last clause of the original Rhetra (Plut. Lyc. 6).

${ }^{40}$ Plut. Lyc. 6, probably following Aristotle (fr. 536 R).
} 
its selling and thereby the concentration of the land into the hands of few rich. ${ }^{41}$ It probably indicates a pressure from the side of the rich on the poor, but at the same time shows that as early as our evidence goes, the Greek states took measures to protect the economic interests of the common people. Obviously, in these states the will of the common people must have been taken into account. In the Classical period such measures were considered to have been characteristic for the middle constitution, not for the oligarchies. ${ }^{42}$ Why, then, should we think that in the early Archaic era the governments that carried on these measures were strictly oligarchic?

From the lyric poetry, especially of Alkaios, Solon and Theognis, we get an impression of grave social tensions between the wealthy and the poor, agathoi and $k a k o i$, and for these poets the political will of the common people was certainly a reality. ${ }^{43}$ For Alkaios and Theognis it was certainly unpleasant, but there is no obvious indication that it was considered as something new. And from the poetry of Solon we get rather contrary impression. For him it was above all the greed and unlawful pretensions of the rich that distorted the normal way of life. ${ }^{44}$ His poetry implies that he was about to restore the old conditions, and he explicitly denied that he had given new rights to the people. ${ }^{45}$ In other words, he seems to have considered himself as a conservative reformer who stopped the rise of the power of the rich, not as a democratic revolutionary trying to give the people the power they had not possessed before. $^{46}$

Thus, the admittedly scarce contemporary evidence from the Archaic era certainly does not suggest an universal process of democratisation, but rather the continual political significance of the common people despite the growing pressure from the nobility.

Let us now make a summary of what has been stated. (1) The Homeric epics do not warrant the point of view that until the end of the 8th century the Greek communities were invariably governed by the kings and nobles, and that the common people were completely excluded from the government. If anything, they suggest that the commoners fought the battles and, correspondingly, must have had some right of taking part in decisions of the political issues. (2) Aristotle's point of view of gradual democratisation was probably his own construction, based on the interpretation of, first, the heroic epics, second, not entirely adequate historical traditions about the early past, and third, more reliable data about the Late Archaic and Classical conditions. Therefore, it cannot be considered as a decisive argument for the social circumstances of the Dark Age and the Early Archaic period. (3) The contemporary data from the Archaic age do not suggest that the common people were excluded from the government. If anything, it suggests that they participated in it from the very beginning and that the early lawgivers were concerned with the preservation of their rights against the growing pressure from the nobility. What evidence do we have, then, to support the usual point of view that the Greek governments were strictly oligarchic at

\footnotetext{
${ }^{41}$ Examples in the Politics of Aristotle: 1265b; 1266b; 1274b; 1319a (the earliest examples recorded by Aristotle are Pheidon of Corinth and Philolaos of Thebes, neither of whom can be dated after the middle of the 7th century). See also Gagarin 1986, 51-80.

42 Asheri 1963.

${ }^{43}$ Alkaios fr. 348 LP; Theognis 53-56; 891-94; Solon fr. 31 GP.

${ }^{44}$ Solon fr. 3, 12 GP.

${ }^{45}$ Solon fr. 7 GP.

${ }^{46}$ This has been recently pointed out by Mitchell 1997. Here one must also note the widespread antiaristocratic tendencies in the archaic poetry (Donlan 1973) or the 'middling position' as called by Morris 1996.
} 
the beginning of the Archaic era, and that the following period of 7th to 5th century was a time of a universal democratisation of Greek society and politics? Is there any reason to suggest that in any time from the Dark Age onwards the people in most Greek communities were under the strict subjection of the nobles? We know that in the Classical period the states were governed in different ways. It would be natural to suggest that the inner organisation of the communities was different already in the Dark Age. Some Dark Age communities may have been, in certain times, ruled by kings, some, perhaps, not. In any case, most of the members of a community probably took charge of its defence and therefore must have shared the responsibility of the government as well. Indeed, without assuming that the notion of the common responsibility for the communal affairs and of the popular participation in the decisionmaking was already a reality in the 8th century, it would be difficult to explain why the Greek nobility in the Archaic period was not able to create a strictly elitarian hierarchic society. It would be natural to suppose that the relatively quick social development from the 9th century onwards, the undeniable growth of wealth and reestablishment of permanent contacts with East must have given new chances above all to the social elite and thus led to the rise of its power. The archaeological data, particularly from Athens and Argos, do not leave much doubt about a prosperous group in the society, anxious of displaying its wealth through the funerals, and there seems to be no reason to deny its identification as the nobility. ${ }^{47}$ Therefore, the 8 th and 7 th centuries must have witnessed a growing pressure of the emerging aristocracy on the other members of community, and not the start of the rise of the previously suppressed common people. The ambitions of the rich and noble obviously must have provoked the reaction of the commoners, and must have been thus the main reason of the social tensions. ${ }^{48}$ The result was that in the late Archaic and the Classical period some states, where the wealthy were successful, developed into relatively strict oligarchies, while some others, where the conditions favoured the common people, developed into radical democracies. Some states, however, seem to have retained basically what may be considered the old traditional way of government - a balance of power between the nobles and the commoners responsible for community's defence that could be called a middle constitution or 'Hoplitenpoliteia'.

All that has been said here is certainly not intended to suggest that in no Greek city any democratisation took place in the course of the Archaic era, or that the Archaic political leaders did not come from the nobility. Nor can it be excluded that in the 8th and 7th century, the period which probably witnessed the emergence of the nobility, the establishment of its economic power and its characteristic way of life, while the means of safeguard of the common people were not yet clearly established, the governments were on the average more oligarchic than later, in the 6th and 5th century. But this can hardly be taken as a universal rule. When we try to reconstruct social conditions and trends of development in the Archaic era, all particular cases must be considered in their own right, without any conceptual prejudice. And there seems to be no compelling reason to admit a priori a general fundamental democratisation of the Greek society during the Archaic and early Classical period.

\footnotetext{
${ }^{47}$ About the archaeological record of late Dark Age and 8th century see especially Coldstream 1977; Snodgrass 1980, 15-84; Morris 1987; 1998; Osborne 1996, 70-136; Whitley 1991; 2001, 98-101, $138-158$.

${ }^{48}$ Recently Raaflaub 1993, 79-80 and especially Donlan 1997 have pointed out that in the Dark Age and in the 8th century the rights of the common people must have been preserved rather well when compared to the time of the aristocratic pressure in the 7 th century.
} 


\section{References}

Andreev, J. (1979) 'Könige und Königsherrschaft in den Epen Homers.' — Klio 61, 361-384.

Andrewes, A. (1956) The Greek Tyrants. London.

Asheri, D. (1963) 'Laws of Inheritance, Distribution of Land and Political Constitutions in Ancient Greece.' - Historia 12, 1-21.

Bowden, H. (1993) 'Hoplites and Homer: Warfare, Hero Cult and the Ideology of the Polis.' - Rich, J., Shipley, G. (Ed.), War and Society in the Greek World, London, New York.

Burkert, W. (1979) 'Das hunderttorige Theben und die Datierung der Ilias.' - Wiener Studien, 10, 5-21.

Busolt, G. (1920) Griechische Staatskunde, I. München.

Carlier, P. (1984) La Royauté en Grèce avant Alexandre. Strassbourg.

Cartledge, P. A. (1977) 'Hoplites and Heroes: Sparta's Contribution to the Technique of Ancient Warfare.' - Journal of Hellenic Studies 97, 11-27.

Cawkwell, G. L. (1996) 'Early Greek Tyranny and People.' - Classical Quarterly $45,73-86$.

Coldstream, J. N. (1977) Geometric Greece. London.

Davies, J. K. (1997) ' Origins of the Greek Polis': Where Should We Be Looking?' - Mitchell and Rhodes 1997, 24-38.

Day, J.; Chambers, M. (1962) Aristotle's History of Athenian Democracy. Berkeley, Los Angeles.

Detienne, M. (2000) 'From Practices of Assembly to the Forms of Politics: a Comparative Approach.' - Arion 7.3, 1-19.

Dickinson, O. T. P. K. (1986) 'Homer, the Poet of the Dark Ages.' - Greece \& Rome 33, 20-37.

Donlan, W. (1997) 'The Relation of Powers in the Pre-State and Early State Communities.' - Mitchell and Rhodes 1997, 39-48.

Donlan, W. (1989) 'The Pre-State Community in Greece.' - Symbolae Osloenses 64, $5-29$.

Donlan, W. (1973) 'The Tradition of Anti-Aristocratic Thought in Early Greek Poetry.' - Historia 22, 144-154.

Drews, R. (1983) Basileus: The Evidence for Kingship in Geometric Greece. New Haven, London.

Ehrenberg, V. (1943) 'An Early Source of Polis-Constitution.' — Classical Quarterly $37,14-18$.

Ehrenberg, V. (1937) 'When did Polis Rise?' - Journal of Hellenic Studies 57, 147159.

Finley, M. (1956) The World of Odysseus. London.

Fisher, N.; van Wees, H., edd. (1998) Archaic Greece: New Approach and New Evidence. London: Duckworth.

Forrest, W. G. (1966) The Emergence of Greek Democracy. London.

Gagarin, M. (1986) Early Greek Law. Berkeley, Los Angeles, London.

Geddes, A. G. (1984) 'Who's Who in Homeric Society?' - Classical Quarterly 34, $17-36$. 
Gehrke, H.-J. (1993) 'Gesetz und Konflikt. Überlegungen zur frühen Polis.' Bleicken J. (Hrsg.), Colloquium aus Anlass des 80. Geburtstages von Alfred Heuss, 49-67, Kallmünz 1993.

Grote, G. (1869) History of Greece. London.

Gschnitzer, F. (1981) Griechische Sozialgeschichte. Wiesbaden.

Hölkeskamp, K.-J. (1992) 'Written Law in Archaic Greece.' - Proceedings of the Cambridge Philological Society 38, 87-117.

Janko, R. (1982) Homer, Hesiod and the Hymns: Diachronic Development of the Epic Diction. Cambridge.

Jensen, M. S. (1980) The Homeric Question and the Oral-Formulaic Theory. Copenhagen.

Kirk, G. S. (1962) The Songs of Homer. Cambridge.

Kõiv, M. (1991) 'Kings and Tyrants in Early Greece.' - Jahrbuch der estnichen Goethe-Gesellchaft, 45-66.

Latatz, J. (1977) Kampfparanäse, Kampfdarstellung und Kampfwirklichkeit in der Ilias, bei Kallinos und Tyrtaios. München.

Libero, L. de (1996) Die archaische Tyrannis. Stuttgart.

Lorimer, H. L. (1950) Homer and the Monuments. London.

Luce, J. V. (1978) 'The Polis in Homer and Hesiod.' — PRIA 78, 1-15.

Mazarakis Ainian, A. (1997) From Ruler's Dwellings to Temples: Architecture, Religion and Society in Early Iron Age Society. Jonsered.

Meyer, Ed. (1893) Geschichte des Altertums, 2. Stuttgart.

Mitchell, L. G. (1997) 'New Wine in Old Wineskins: Solon, Arete and Agathos.' Mitchell and Rhodes 1997, 137-147.

Mitchell, L. G.; Rhodes, P. J., edd. (1997) The Development of the Polis in Archaic Greece. London, New York.

Morris, I. (1998) 'Archaeology and Archaic Greek History.' - Fisher and van Wees $1998,1-91$.

Morris, I. (1996) 'The Strong Principle of Equality and the Archaic origins of Greek Democracy.' - Ober, J. and Hendrick, C. W. (edd.), Demokratia. A Conversation on Democracies Ancient and Modern, 19-48, Princenton 1996.

Morris, I. (1987) Burial and Ancient Society. Cambridge.

Morris, I. (1986) 'The Use and Abuse of Homer.' - Classical Antiquity 5, 81-138.

Mosse, C. (1969) La tyrannie dans la Grèce ancienne. Paris.

Murray, O. (1980) Early Greece. Glasgow.

Nagy, G. (1992) 'Homeric Questions.' - Transactions and Proceedings of American Philological Association 122, 17-60.

Nagy, G. (1990) Pindar's Homer: The Lyric Possession of an Epic Past. Baltimore.

Nilsson, M. P. (1929) 'Die Hoplitentaktik und das Staatwesen.' - Klio 22, 240-249.

Oliva, P. (1960) 'Die Bedeutung der frühgriechischen Tyrannis.' — Klio 38, 81-86.

Osborne, R. (1997) 'Law and Laws: How do We Join up the Dots?' - Michell and Rhodes 1997, 74-82.

Osborne, R. (1996) Greece in the Making, 1200 - 479 BC. London, New York.

Polignac. F. de (1984) La naissance de la cité grecque. Paris.

Qviller, B. (1981) 'The dynamics of the Homeric society.' - Symbolae Osloenses 56, $109-155$.

Pritchett, W. K. (1985) The Greek State at War. Berkeley, Los Angeles.

Raaflaub, K. A. (1998) 'A Historian's Headache: How to Read 'Homeric Society'?' — Fisher and van Wees 1998, 169-193. 
Raaflaub, K. A. (1997) 'Soldiers, Citizens and the Evolution of the Early Greek Polis.' - Michell and Rhodes 1997, 49-59.

Raaflaub, K. A. (1993) 'Homer to Solon. The Rise of the Polis. Written Sources.' Hansen, M. H. (ed.), The Ancient Greek City-State, 41-105. Copenhagen 1993.

Runciman, W. G. (1982) 'Origins of States: The Case of Archaic Greece.' - Comparative Studies in Society and History 24, 351-377.

Ruschenbusch, E. (1958) 'Patrios Politeia: Theseus, Drakon, Solon und Kleisthenes in Publistik und Geschichtschreibung des 5. und 4. Jahrhunderts v. Chr.' - Historia 7, 398-424.

Salmon, I. B. (1977) 'Political Hoplites.' - Journal of Hellenic Studies 97, 84-101.

Scully, S. (1990) Homer and the Sacred City. Ithaca, London.

Sherrat, E. S. (1990) 'Reading the Text: Archaeology and the Homeric Question.' Antiquity 64, 804-827.

Snodgrass, A. M. (1980) Archaic Greece: The Age of Experiment. Berkeley, Los Angeles.

Snodgrass, A. M. (1974) 'An Historica Homeric Society?' - Journal of Hellenic Studies 94, 114-125.

Snodgrass, A. M. (1965) 'The Hoplite Reform and History.' - Journal of Hellenic Studies 85, 110-122.

Spahn, P. (1977) Mittelschicht und Polisbildung. Frankfurt.

Stahl, M. (1987) Aristokraten und Tyrannen im archaischen Athen. Wiesbaden.

Starr, C. G. (1986) Individual and Community: The Rise of the Polis 800-500 B.C. New York, Oxford.

Stein-Hölkeskamp, E. (1989) Adelskultur und Polisgesellschaft. Studien zum griechischen Adel in archaischer und klassischer Zeit. Stuttgart.

Thomas, C. G. (1966) 'Homer and the Polis.' — La parola del passato 21, 1-14.

Thomas, C. G.; Conant, C. (1999) Citadel to City-State: Transformation of Greece 1200-700 B.C.E. Bloomington, Indianapolis.

Ulf, C. (1990) Die homerische Gesellschaft. München.

Vansina, J. (1985) Oral tradition as History. London, Nairob.

Walter, U. (1993) An der Polis teilhaben: Bürgerstaat und Zugehörigkeit im archaischen Griechenland. Stuttgart.

Wees, H. van (1994) 'The Homeric Way of War: Iliad and the Hoplite Phalanx.' Greece \& Rome 41, 138-146.

Wees, H. van (1992) Status Warrior: War, Violence and Society in Homer and History. Amsterdam.

Welwei, K.-W. (1983) Die griechische Polis: Verfassung und Gesellschaft in archaischer und klassischer Zeit. Stuttgart, Berlin, Köln, Mainz.

West, M. L. (1995) 'The Date of the Iliad.' - Museum Helveticum 52, 203-219.

West, M. L. (1988) 'The Rise of Greek Epic.' - Journal of Hellenic Studies 108, $151-172$.

West, M. L. (1973) 'Greek Poetry 2000-700 B.C.' - Classical Quarterly 67, 179192.

Whitely, J. (2001) The Archaeology of Ancient Greece. Cambridge.

Whitely, J. (1998) 'Literacy and Lawmaking: the Case of Archaic Crete.' - Fisher and van Wees 1998, 311-331.

Whitely, J. (1991) Style and Society in Dark Age Greece. Cambridge. 